\title{
PLAN OF STUDY FOR THE REGIONAL AQUIFER- SYSTEM ANALYSIS OF THE NORTHERN ROCKY MOUNTAINS INTERMONTANE BASINS, MONTANA AND IDAHO
}

by DAVID W. CLARK and ELOISE KENDY

U.S. GEOLOGICAL SURVEY

Water-Resources Investigations Report 92-4116

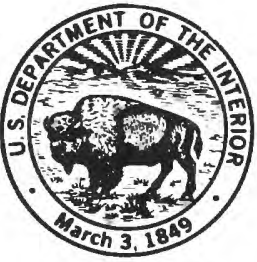

Helena, Montana

October 1992 


\title{
U.S. DEPARTMENT OF THE INTERIOR \\ MANUEL LUJAN, JR., Secretary
}

\author{
U.S. Geological Survey
}

DALLAS L. PECK, Director

For additional information write to:

District Chief

U.S. Geological Survey

428 Federal Building

301 South Park, Drawer 10076

Helena, MT 59626-0076
Copies of this report can be purchased from:

U.S. Geological Survey

Books and Open-File Reports Section

Federal Center

Box 25425

Denver, CO 80225-0425 


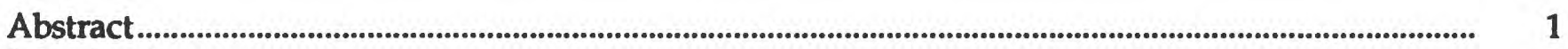

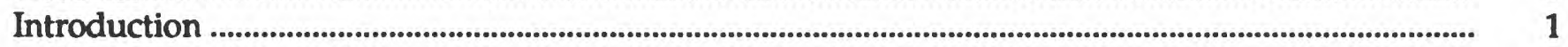

Purpose and scope.................................................................................................................................................... 3

Description of study area ......................................................................................................................................... 3

Hydrogeologic framework..................................................................................................................................... 5

Bedrock geology and structure ............................................................................................................................ 5

Tertiary and Quaternary deposits .............................................................................................................. $\quad 7$

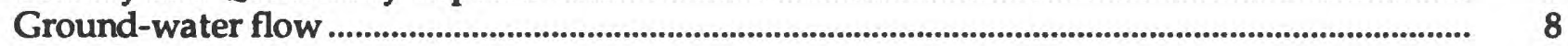

Plan of study .................................................................................................................................................................... 9

Objectives and approach ............................................................................................................................... 10

Work elements ............................................................................................................................................... 10

Hydrogeologic framework ......................................................................................................................... 10

Hydrology ..................................................................................................................................................... 11

Geochemistry ................................................................................................................................................... 12

Geographic information system.............................................................................................................. 13

Report products................................................................................................................................... $\quad 14$

Organization and staffing .......................................................................................................................................... 14

References cited ....................................................................................................................................................................... 15

\section{ILLUSTRATIONS}

Figures 1-3. Maps showing:

1. Location of study area

2. Distribution of intermontane basins

3. Generalized geology of the Northern Rocky Mountains

4. Diagram showing schedule of work elements

\section{CONVERSION FACTORS}

\section{Multiply}

foot (ft)

foot squared per day

$\left[\left(\left(\mathrm{ft}^{3} / \mathrm{d}\right) / \mathrm{ft}^{2}\right) \mathrm{ft}\right.$ or $\left.\mathrm{ft}^{2} / \mathrm{d}\right]$

gallon per minute (gal/min)

inch (in.)

mile

million gallons per day (Mgal/d)

square mile $\left(\mathrm{mi}^{2}\right)$
By

\subsection{8}

0.0929

0.06309

25.4

1.609

0.04381

2.59

\section{Te obtain}

meter

meter squared per day

liter per second millimeter

kilometer

cubic meter per second square kilometer 


\title{
PLAN OF STUDY FOR THE REGIONAL AQUIFER-SYSTEM ANALYSIS OF THE NORTHERN ROCKY MOUNTAINS INTERMONTANE BASINS, MONTANA AND IDAHO
}

\author{
By David W. Clark and Eloise Kendy
}

\begin{abstract}
The U.S. Geological Survey has begun a Regional Aquifer-System Analysis of the Northern Rocky Mountains of western Montana and central and northern Idaho. The analysis will establish a regional framework of information for aquifers in about 70 intermontane basins in an area of 80,000 square miles. In that area, these basins, which are regionally unified by their common geologic histories, are filled with unconsolidated to poorly consolidated Tertiary and Quaternary deposits as much as 16,000 feet thick and are separated by Archean to Quaternary bedrock. Alluvial and glacial deposits generally are the most productive shallow aquifers. In many areas, ground water is the only suitable source of supply, yet little information is available about this valuable resource on either a local or a regional scale.

This report describes a plan of study for increasing and quantifying knowledge of the hydrogeology of aquifers in these intermontane basins. Specifically, the report describes the plan of study in terms of objectives and approach, work elements, and organization and staffing. In addition, the report delineates and describes the study area and the hydrogeologic framework in terms of the generalized geology and structure of bedrock, the type and character of Tertiary and Quaternary basin-fill deposits, and the ground-water flow.
\end{abstract}

\section{INTRODUCTION}

In 1978, the U.S. Geological Survey (USGS) began a Regional Aquifer-System Analysis (RASA) Program, as mandated by Congress, to determine the aquifer boundaries, the quantity and quality of the water within the aquifers, and the recharge characteristics of the aquifer systems within the United States (Sun, 1986, p. 2). The Northern Rocky Mountains Intermontane Basins (fig. 1) was one of the 28 regional aquifer systems initially chosen.

Numerous intermontane basins in western Montana and northern and central Idaho contain consolidated to poorly consolidated basin-fill deposits of Tertiary and Quaternary age that commonly are saturated with water. In many areas, these deposits are the only source of water of adequate quantity and suitable quality for public-supply, domestic, stock, irrigation, commercial, and industrial use. Regional and local concerns about ground-water availability and quality are numerous. However, little information is available about this valuable resource on either a local or a regional scale.

About 70 hydrologic studies have been conducted within the study area, beginning as early as 1912 (Meinzer, 1914) and continuing to the present (1992). Most of these studies were local, included only about one-fourth of the individual basins, and generally focused on shallow ground-water systems. From these studies, ground water is known to be available in most valleys at depths of less than $100 \mathrm{ft}$; yet, the potential availability of large quantities of water, particularly from deeper parts of the aquifers, is largely unknown. Although shallow ground water is generally suitable for most uses, the shallow depth to water makes the aquifer susceptible to contamination from surface activities. Also, some local water-quality problems are known, but the occurrence or magnitude of problems on a regional scale is 


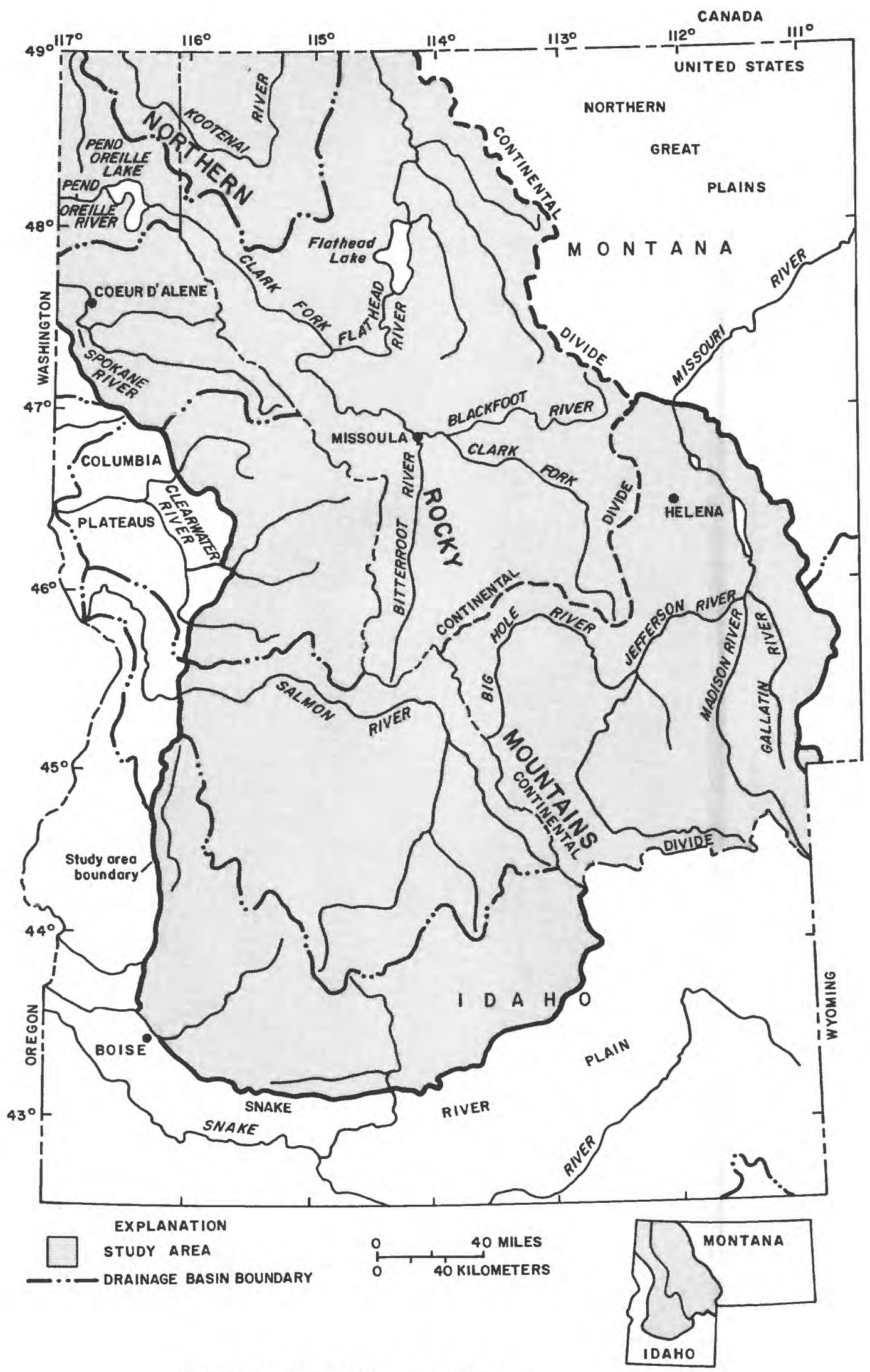

Figure 1.--Location of study area. 
not known. Even though some basins have been studied individually, little consideration has been given to the hydraulic interconnection or regional similarities between basins. This study will provide a basis for a greater understanding of the regional hydrologic system through data-base compilation and interpretation, and hydrogeologic-framework definition.

\section{Purpose and Scope}

This report is a plan of study for increasing and quantifying knowledge of the hydrogeology of aquifers in intermontane basins of the Northern Rocky Mountains. Specifically, the report describes the plan of study in terms of its objectives and approach, work elements, and organization and staffing. In addition, the report delineates and describes the study area and the hydrogeologic framework in terms of the generalized geology and structure of bedrock, the type and character of Tertiary and Quaternary basinfill deposits, and the ground-water flow.

\section{Description of Study Areg}

The Northern Rocky Mountains Intermontane Basins RASA study area encompasses about 80,000 $\mathrm{mi}^{2}$. The study area extends westward from the Northern Great Plains RASA study area in Montana to the Columbia Plateaus RASA study area in western Idaho, and northward from the Snake River Plain RASA study area in Idaho to the United States-Canada border (fig. 1). The study focuses on aquifers within basin-fill deposits in western Montana and central and northern Idaho. For purposes of this study, "basin" refers to structurally defined areas and features that contain unconsolidated to poorly consolidated deposits.

About 70 basins have been delineated in the study area on the basis of stratigraphy, geologic structure, and results of previous studies (fig. 2). Although separated geographically, many basins have hydrogeologic characteristics that are similar because of common structural and depositional histories and physiographic settings. Basins range in size from about 10 to $400 \mathrm{mi}^{2}$ and are filled with unconsolidated to poorly consolidated Tertiary and Quaternary continental deposits. These deposits generally range from several hundreds to several thousands of feet in thickness and are known to be as much as $16,000 \mathrm{ft}$ thick.

The Continental Divide (fig. 1) separates the area into two major drainage systems--the Missouri River drainage to the east and the Columbia River drainage to the west. Major streams in the Missouri River drainage include the Big Hole, Jefferson, Madison, and Gallatin Rivers. Major streams in the Columbia River drainage include the Snake, Salmon, Clearwater, Spokane, Clark Fork/Pend Oreille, Blackfoot, Bitterroot, Flathead, and Kootenai Rivers.

Annual precipitation ranges from about $8 \mathrm{in}$. in basins of east-central Idaho to about $100 \mathrm{in}$. in some mountainous parts of Montana; however, most valleys receive 10 to 30 in. of precipitation per year. More than 50 percent of the annual precipitation occurs as snow from November to April. Winter snowpack in the mountains serves as a storage reservoir that slowly releases snowmelt and maintains streamflow well into summer.

The topography of the area is varied. In the northwest corner of Montana and in central Idaho, mountain ranges are separated by narrow, steep-sided valleys that have little or no fill material--primarily the result of erosion by glaciers and streams. In contrast, the ranges of southwestern Montana and eastcentral and northern Idaho are separated by wide, relatively level valleys that are deeply filled with sediment--the result of basin collapse due to block faulting. Tertiary and Quaternary deposits beneath these valleys are the focus of this study. 


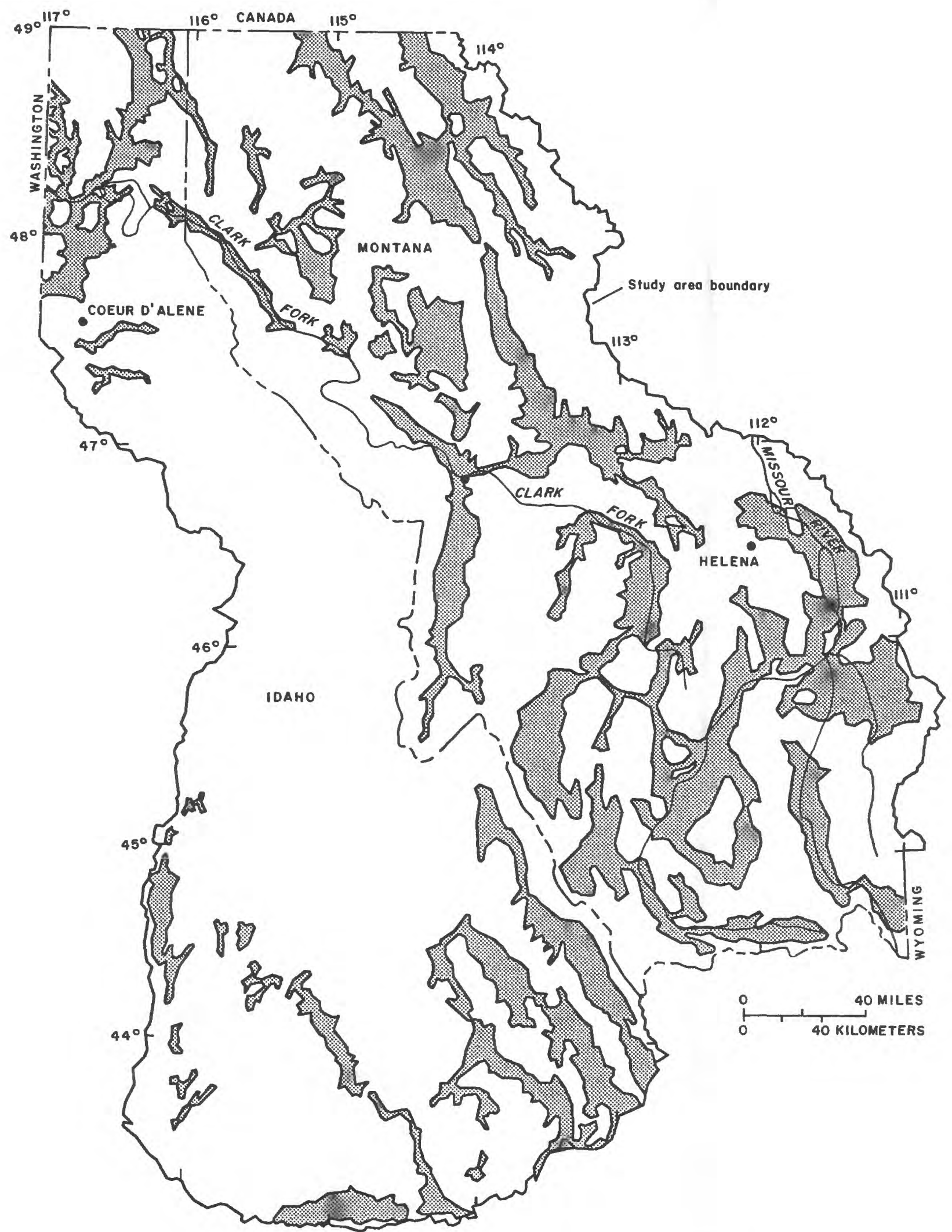

Figure 2.-Distribution of intermontane basins (patterned). 
Aquifers in Tertiary and Quaternary deposits provide water for public-supply, domestic, stock, irrigation, commercial, and industrial use. The largest use of ground water is for irrigation and public supply, although most water for irrigation is obtained from surface-water sources. Most residents rely on ground water from wells or springs for drinking and other domestic use. Total ground-water withdrawals in 1985 were about $400 \mathrm{Mgal} / \mathrm{d}-300 \mathrm{Mgal} / \mathrm{d}$ in Idaho and $100 \mathrm{Mgal} / \mathrm{d}$ in Montana.

\section{Hydrogeologic Framework}

Ground-water flow in each basin is controlled primarily by the distribution and nature of deposits that compose the basin-fill aquifers. These deposits were derived from the rocks surrounding the basins; the geologic processes that created the basins controlled deposition of the fill material. Therefore, knowledge of the regional geologic framework is necessary to understanding the hydrogeology of the basin-fill aquifers.

\section{Bedrock Geology and Structure}

Individual basins are isolated by mountains consisting of various rock types that span the geologic time scale. This diverse assemblage of bedrock has been simplified into five general categories on the basis of age, lithology, areal distribution, and hydraulic properties. In ascending order, these categories are: (1) Archean basement rocks, (2) rocks of the Middle Proterozoic Belt Supergroup, (3) Paleozoic and Mesozoic sedimentary rocks, (4) Cretaceous to Tertiary plutonic rocks, and (5) Cretaceous to Quaternary volcanic rocks (fig. 3 ).

Archean basement rocks consisting of marble, metaquartzite, schist, and gneiss presumably underlie the entire study area, but crop out only in the southeastern part. Northwest- and northeast-striking, highangle reverse faults dominate the structure of the outcrop area.

Rocks of the Middle Proterozoic Belt Supergroup are exposed in isolated places in the southern part of the study area, and throughout the northern part, where thicknesses may exceed 60,000 ft. Rocks in this sequence were originally deposited as fine-grained terrigenous and carbonate sediment in a narrow, subsiding basin; subsequently, the rocks underwent regional low-grade metamorphism to argillite and quartzite. Terrane of the Belt Supergroup in the north has been deformed by large, widely spaced, subparallel, high-angle faults and broad folds that trend northerly to northwesterly.

Several thousand feet of Paleozoic and Mesozoic sedimentary rocks crop out in the southern and eastern parts of the study area, where they are extensively folded and thrust faulted. The Paleozoic units are mostly marine carbonate rocks that underlie Mesozoic marine and coastal-plain shale, sandstone, and limestone. Most of these sedimentary rocks have little porosity; however, Mississippian limestone of the Madison Group, which is cavernous in places, may be an important source of recharge to basin-fill aquifers, as well as a possible conduit for ground-water flow between basins.

From Cretaceous to early Tertiary time, large volumes of magma intruded the bedrock of the Northern Rocky Mountains. The two major plutonic complexes that resulted are the granitic, granodioritic, and quartz dioritic Idaho Batholith in central Idaho (Ross and Forrester, 1958) and the quartz monzonitic Boulder Batholith in Montana (Hyndman, 1979). Intermontane basins (fig. 2) are generally absent in areas of batholith (fig. 3 ).

Approximately contemporaneous with and following batholith intrusion, several episodes of volcanic activity emplaced thousands of feet of volcanic rocks on top of and adjacent to the intrusive rocks. The volcanic rocks include mafic to silicic flows, breccias, volcaniclastics, and tuffs of Cretaceous through Pleistocene age. Permeability of most volcanic rocks is generally less than that of the basin-fill sediments; however, secondary permeability caused by fracturing might be substantial in places. 


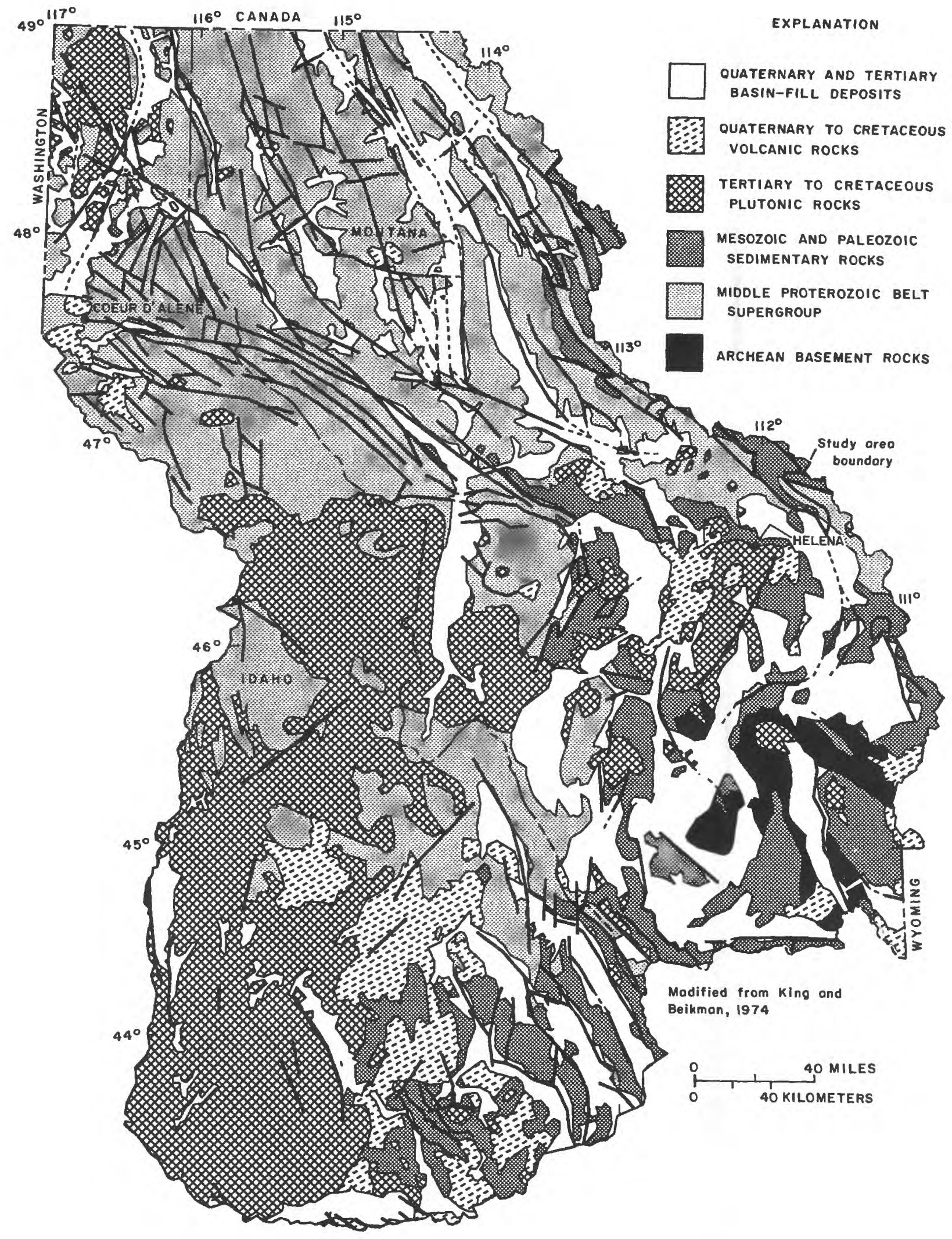

Figure 3.--Generalized geology of the Northern Rocky Mountains. 
Most investigators agree that the intermontane basins of the Northern Rocky Mountains attained their modern configurations during the Miocene Epoch, when Basin and Range tectonics created an area of broadly distributed crustal extension characterized by hundreds of normal faults. As the crust extended, downthrown fault blocks became basins, while upthrown blocks became the intervening mountains (Eaton, 1979). The primary basin trend is northerly to northwesterly, roughly parallel to basinmargin normal faults and perpendicular to regional extension.

The Basin and Range faulted area includes all basins in the study area south of the Lewis and Clark line, which is a linear zone of high-angle faults (fig. 3 ) having predominantly strike-slip displacement that extends from about lat $47^{\circ} 45^{\prime}$, long $116^{\circ} 45^{\prime}$ (near Coeur d'Alene, Idaho) to lat $46^{\circ} 30^{\prime}$, long $112^{\circ}$ (near Helena, Mont.) (Wallace and others, 1990). Basins north of the Lewis and Clark line are also Miocene extensional features. However, the long, straight geometries and the seismic stability of these basins distinguish them from the typically short, curvilinear, seismically active basins to the south (Reynolds, 1979; Stickney and Bartholomew, 1987). In the broadest sense, the basin morphology north of the Lewis and Clark line is different because of the effects of Basin and Range tectonics on preexisting structures that were different from those south of the line (David Lageson, Montana State University, Professor of Earth Sciences, written commun., 1991).

The structures that define the present-day basins have dominated tectonic features of the basins throughout, and probably prior to, the Cenozoic Era (Fields and others, 1985). Many basin-marginal faults probably originated as early as Precambrian time (Ruppel, 1982). During the Late Cretaceous-Paleocene (Laramide) orogeny, thrust faults formed along these faults and other preexisting planes of structural weakness. In early Tertiary time, basins may have first appeared as a result of listric normal movement along the thrust planes (Fields and others, 1985). When the modern phase of Basin and Range extension began in the Miocene Epoch, normal faults preferentially formed on preexisting planes, and the modern structural basins formed and filled with sediment.

In the southern part of the study area, extension and uplift associated with the Snake River Plain have been superimposed on the regional Basin and Range stress field (Stickney and Bartholomew, 1987). The evolution of both the Snake River Plain and the adjacent basins may coincide with the track of a hot spot or mantle plume moving northeastward relative to the crustal plate (Mabey, 1982). Basin-margin faults defining the few east-west trending intermontane basins adjacent to the Snake River Plain are related more closely to Snake River Plain tectonics than to Basin and Range tectonics, although the effects of both are evident (Johnson, 1981; Sonderegger and others, 1982).

\section{Tertiary and Quaternary Deposits}

Basin subsidence, tectonism, and volcanism, which occurred intermittently throughout the Tertiary Period, resulted in continental deposits as thick as $16,000 \mathrm{ft}$. In southwestern Montana, these deposits have been named the Bozeman Group, which consists of the Renova Formation and the Sixmile Creek Formation. Names for Tertiary deposits vary within the study area, but the stratigraphy is generally correlative on a regional basis.

Historically, the lower predominantly fine-grained deposits of Eocene to early Miocene age have been named the Renova Formation, whereas the overlying predominantly coarse-grained deposits of middle Miocene to middle Pliocene age have been named the Sixmile Creek Formation. However, recent work on the stratigraphy of the Tertiary deposits indicates that fine-and coarse-grained deposits occur in both formations (Hanneman and Wideman, 1991). Both the Renova and the Sixmile Creek Formations consist of lacustrine and fluvial sediments that exhibit abrupt lateral and vertical facies changes. Ashflow tuff, tuff, and debris-flow and fluvial-channel derived conglomerates and sandstones are complexly stratified with flood-plain derived coal, mudstone, siltstone, and sandstone (Hanneman and Wideman, 1991). The Renova Formation, with its base as much as $16,000 \mathrm{ft}$ below land surface in some basins, is generally considered to be too deep and not sufficiently permeable to be a viable aquifer. In contrast, the 
uppermost gravels of the Sixmile Creek Formation form the most productive deep aquifer in the basins (Noble and others, 1982) and locally may yield more than $500 \mathrm{gal} / \mathrm{min}$.

The extent of Tertiary and Quaternary deposits (fig. 3) in some areas does not coincide with the modern basin boundaries (fig. 2). Differential uplift of the basins resulted in exposures of some of these deposits outside the modern basins, which were created, in part, by Basin and Range tectonics. Continued faulting, tilting, and erosion of the Tertiary deposits since the Miocene created the present pediments and drainage systems.

Quaternary fluvial and glacial deposits overlie some Tertiary deposits. In southern basins, Quaternary deposits consist primarily of Holocene alluvium along streambeds, and colluvial and alluvial-fan deposits near mountain flanks. In northern basins, glaciers reworked pre-Pleistocene surfaces and contributed glacial sediments prior to Holocene alluvial deposition.

The northern basins were subjected to repeated glacial advances, inundation by glacial lakes, and lastly, alluvial deposition (Alden, 1953). Glacial deposits in the intermontane basins range in thickness from a few feet to hundreds of feet (Noble and others, 1982) and consist primarily of till and outwash. Till is typically heterogeneous and has grain sizes ranging from clay to boulders in an unsorted mixture with local stringers of sand and gravel. Till generally is not a productive aquifer, and in places confines other aquifers. Sediment-laden, braided streams deposited glaciofluvial outwash--chiefly sand and gravel--in broad stream valleys. Although outwash also may be heterogeneous, it is a productive aquifer in places.

At least $\mathbf{4 0}$ times during Cordilleran glaciation, glacial-ice dams blocked the Clark Fork drainage at the present site of Pend Oreille Lake in Idaho and impounded drainage from northwestern Montana, filling Glacial Lake Missoula (Chambers, 1984). At its maximum extent, the glacial lake occupied six major intermontane basins. The "type" section of the resulting glaciolacustrine deposits consists of about 40 cyclic sequences of clay, silt, and very fine sand (Chambers, 1984). These deposits are restricted to the valley floors, where they may overlie more permeable glacial deposits. Glaciolacustrine deposits may exceed $300 \mathrm{ft}$ in thickness and generally thin toward the valley sides. Other glacial lakes produced similar deposits; the largest of these was Glacial Lake Kootenai, which formed in the northern basins of the study area. The glaciolacustrine deposits typically form confining units.

Holocene alluvium overlies glacial deposits in the north and Tertiary deposits in the south. The most significant of these deposits in terms of water yield is alluvium along streams, and to a lesser degree alluvial fans along the basin margins. Alluvium along streams generally is composed of moderately sorted to well-sorted silt, sand, and gravel. Typically, alluvium ranges in thickness from 10 to $200 \mathrm{ft}$, is laterally extensive parallel to the stream, and thins in a direction perpendicular to the stream. Older alluvium may crop out as gravel terraces paralleling the modern streambed. With typical transmissivities in the range of 10,000 to $100,000 \mathrm{ft}^{2} / \mathrm{d}$, alluvial aquifers generally are capable of yields suitable for irrigation and municipal water supplies. Alluvium along streams is the most productive aquifer in the study area.

Alluvial fans consist of a heterogeneous mixture of clay- to boulder-sized sediments that generally decrease in size from the apex to the toe of the fan. Within the typical fan deposit, homogeneous lenses and stringers dip away from the mountain front. Alluvial-fan deposits in the study area are as much as $500 \mathrm{ft}$ thick. Although present in most basins, alluvial fans are probably best developed in the more arid, southern basins, where large coalescing alluvial fans are still forming (Fields and others, 1985).

\section{Ground-Water Flow}

Many basin-fill aquifers are constricted within bedrock canyons at the downgradient ends of the intermontane basins. Therefore, flow systems within the basin fill are largely restricted to the basins themselves, with little or no known hydraulic connection between unconsolidated deposits of adjacent basins. Throughflowing streams, however, provide hydraulic connection between basins. For example, 
surface water used for irrigation in one basin can infiltrate to become ground water, flow downgradient until it discharges as surface water, then flow to the next basin, where it may again be diverted and used for irrigation.

Although most bedrock surrounding the basins is impermeable relative to the basin fill, some ground water might flow between basins along zones of geologic weakness or through locally permeable bedrock. Some faults of the Lewis and Clark line, for example, might have zones of increased permeability, owing to extensive areas of shattered rock or brecciation (Wallace and others, 1990), that would conduct ground water between basins. Deep circulation of water along Tertiary and Quaternary extension faults (Perry, 1988) could be another conduit for interbasin ground-water flow. Interbasin groundwater flow in some areas is probably a minor part of the total ground-water budget.

Aquifers in Quaternary deposits may be unconfined, leaky confined, or confined. Most shallow alluvial aquifers are unconfined. In northern parts of the study area, some aquifers are confined by overlying glaciolacustrine deposits or till. Fine-grained layers within the Tertiary deposits might confine more permeable layers. With depth, these fine-grained layers become more consolidated and, therefore, less permeable. Although some aquifers in Tertiary deposits have recently been developed, hydrogeologic information about them is sparse. With few exceptions, aquifers in Quaternary and Tertiary deposits within a basin are assumed to be hydraulically connected.

Although hydrologic budgets have been estimated for only a few basins, natural recharge and discharge are assumed to be the dominant components in most basins. Aquifers are recharged by leakage from streams, subsurface inflow from surrounding bedrock near the mountain front, and to a minor extent by direct infiltration of precipitation. Infiltration of applied irrigation water and leakage from irrigation canals also provide recharge. Aquifers are discharged by evapotranspiration, pumping, seepage to springs, and leakage to rivers and streams, which generally is the largest component of discharge.

The configuration of the water levels in the shallow alluvial aquifers reflects the topography, with flow components trending toward major streams and downvalley. The direction of lateral flow in deeper aquifers may be different than in shallow aquifers in response to confining strata, faulting, or other deep structural controls. Vertical flow between aquifers is dependent upon location and in most basins is poorly defined. Depth to ground water ranges from zero feet at springs and wetlands to hundreds of feet in the topographically high areas near basin margins.

\section{PLAN OF STUDY}

The Northern Rocky Mountains Intermontane Basins RASA was initiated in fiscal year 1990 and is scheduled to be funded through fiscal year 1995. During the first complete year of study (fiscal year 1991), work was directed toward staffing, defining critical work elements, compiling and analyzing existing information, determining data needs, supplementing the data base, and preliminarily defining the ground-water hydrology. During the central years of study, work will be directed toward constructing a geographic information system (GIS) data base, collecting supplemental data, developing and evaluating methods to determine components of ground-water budgets, and preparing initial reports and maps. During the final years, efforts will be directed to using the complete data base to analyze regional aspects of the aquifer systems, to document the GIS data base, and to prepare final reports.

${ }^{1} \mathrm{~A}$ fiscal year is the 12-month period October 1 through September 30 . It is designated by the calendar year in which it ends. 


\section{Objectives and Approach}

The general objectives of the overall U.S. Geological Survey's RASA studies are described by Sun (1986). The objectives of this study are to increase and quantify the knowledge of the hydrogeology of the major intermontane basin aquifers in the Northern Rocky Mountains.

The basic approach of this study will be similar to that of other RASA studies; that is, to compile the available geologic, hydrologic, and geochemical data and to use these data to describe the aquifer systems. However, this RASA study differs from the others in some important respects. First, this study encompasses several discrete aquifers rather than one large, regional aquifer. Therefore, no regional ground-water flow model will be developed. Second, RASA studies were designed to incorporate all existing information and to interpret it in terms of the regional hydrogeologic system. However, existing data for the study area are insufficient to justify regional interpretations. Of the approximately one-fourth of the basins that have been previously studied, primarily on a reconnaissance level, only a few contain data on hydraulic properties, and even fewer present comprehensive ground-water budgets. Only one basin has been simulated with a ground-water flow model, and the historical data necessary to develop more models are lacking for most basins. Consequently, this study will need to collect considerable data to supplement existing data bases.

\section{Work Elements}

This section describes work elements for the hydrogeologic framework, hydrology, geochemistry, GIS, and reports components. The approximate scheduling of these work elements is shown in figure 4.

\section{Hydrogeologic Framework}

The hydrogeologic framework primarily will be a summary of pertinent existing information describing geology as it relates to ground water. Little additional geologic data will be collected. This component of the study will not include quantitative analysis of hydraulic properties of the bedrock and basin-fill deposits, but might include qualitative descriptions of their water-yielding characteristics.

The following tasks are needed to complete this component of study:

1. Complete and review available information on bedrock geology, regional structure, and Tertiary and Quaternary deposits.

a. Simplify the diverse assemblage of bedrock lithologies into five to eight general categories on the basis of hydrogeologic similarity, areal distribution, age, and lithology.

b. Compile geologic-map data from several sources: primarily from State maps of Idaho and Montana at a scale of 1:500,000; from newer geologic maps at a scale of 1:250,000, either from paper or, where possible, from digital data bases of those maps; and from selected-area maps at a scale of $1: 100,000$ or larger.

c. Compile data and information on water-yielding characteristics of bedrock, on regional structure, and on geologic history of the Tertiary and Quaternary basin-fill deposits.

d. Compile gravity and other geophysical data.

2. Evaluate and interpret the data base.

a. Produce a hydrogeologic map of the study area at a scale of 1:750,000 that shows the generalized distribution of bedrock geology and structural features, and includes hydrogeologic information in an accompanying text. 


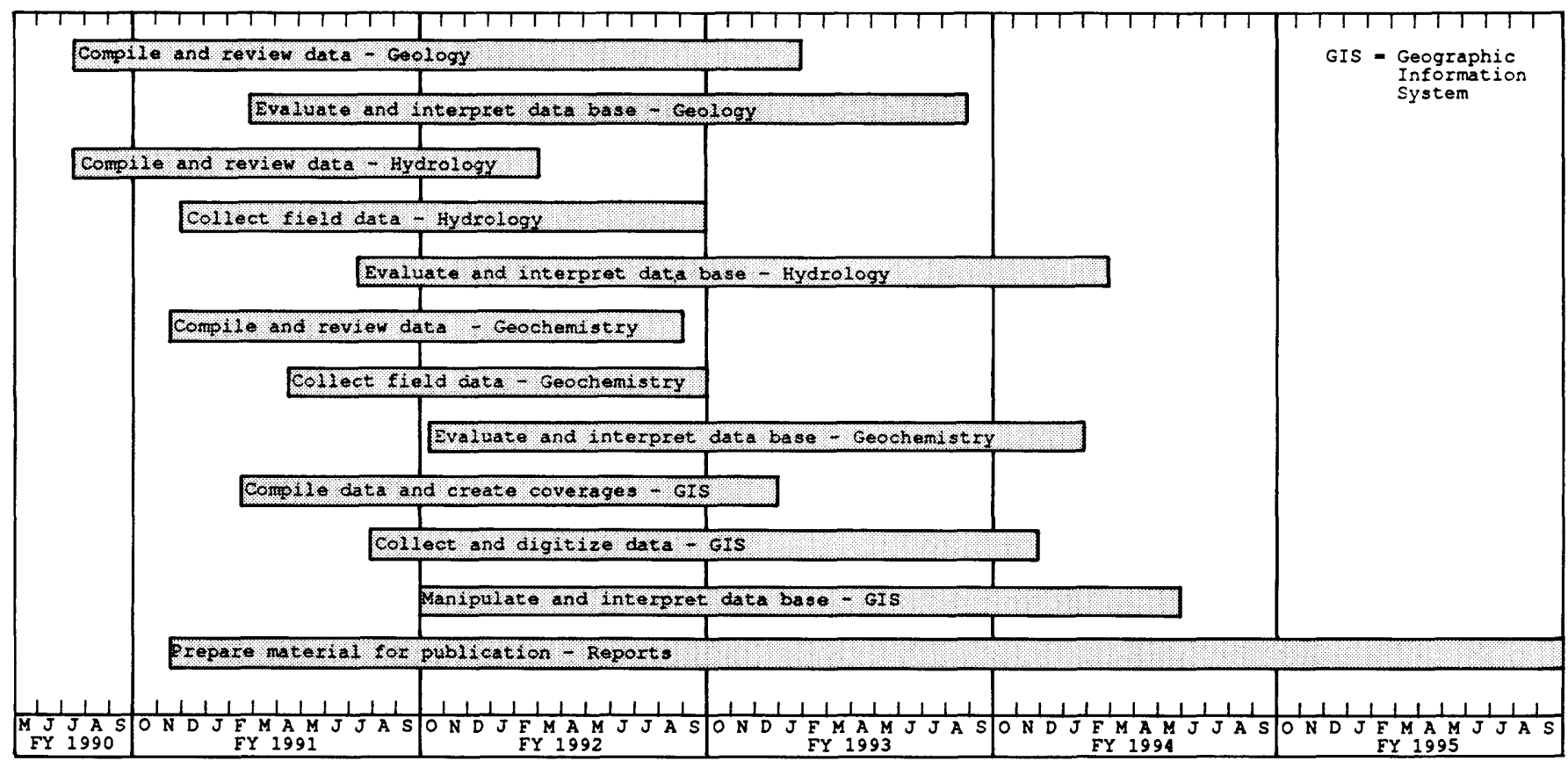

Figure 4.--Schedule of work elements.

b. Produce diagrammatic sections of some representative basins.

c. Summarize the generalized hydrogeology of the Tertiary and Quaternary basin-fill deposits, including, where possible, the age, lithology, thickness, depositional environment, and water-yielding characteristics.

\section{Hydrology}

Primary emphasis will be given to the collection, compilation, quality evaluation, and interpretation of hydrologic data for the basin-fill aquifers. Existing data are unevenly distributed; numerous data are available for recently studied basins, whereas little or no data are available for most basins. Where data are sparse and unevenly distributed, emphasis will be given to developing and using methods to study attributes that are unique to the study area to produce supplemental data that will help to achieve a more even distribution. Analyses will not include large-scale ground-water-flow models, because a regional ground-water flow system is lacking in the study area.

The following tasks are needed to complete this component of study:

1. Compile and review available USGS hydrologic data.

a. Compile data and information from all pertinent literature.

b. Compile all well-inventory data, including water levels, hydrographs, and potentiometric heads, and, where appropriate, enter into the digital data base.

c. Compile data from previously calculated ground-water budgets, including estimates of quantities and sources of recharge to, and natural discharge from, the basins.

d. Compile data on hydraulic properties.

e. Compile data on discharge from wells.

f. Compile surface-water records. 
2. Collect field data and data from other sources; emphasis will be on basins where ongoing programs are not likely to generate new data.

a. Complete an intensive well inventory during the initial part of the study. Collect data in basins, or parts of basins, not previously studied to improve data bases of potentiometric head, specific capacity, and hydraulic characteristics.

b. Collect and review data on ground-water withdrawals by wells, particularly for large-scale agricultural, public-supply, commercial, and industrial use.

c. Collect and review data related to hydraulic properties of the basin-fill aquifers from nonUSGS sources.

d. Collect field data from selected areas using various techniques, possibly including surface geophysics, shallow test drilling, water-level monitoring, aquifer testing, and low-flow investigations of streams. Select areas that are representative in terms of hydrogeology, water use, or development.

3. Evaluate and interpret the data base.
a. Produce a potentiometric-surface map or maps of the study area at a scale of 1:750,000 using data collected during the initial part of the study, and, if practical, produce a map of the depth to principal water-yielding zones.
b. Interpret the data collected in selected basins during the study to address specific hydrologic concerns.
c. Estimate hydraulic characteristics of basin fill and bedrock from statistical analysis of point data and from analysis of streamflow hydrographs.
d. Define and, where possible, quantify the major components of the ground-water budget, including recharge, natural discharge, and pumpage.
e. Use profile, coarse-scale, and conceptual steady-state models of selected areas to assist in understanding the ground-water flow system and hydrologic budget.
f. Describe the conceptual model of the ground-water systems in type basins and the relations and comparisons among water-budget components.

\section{Geochemistry}

The primary emphasis of this component of study is to develop a framework of information that describes the quality of water in aquifers in the intermontane basins at both local and regional scales. Much of the information in existing data bases is unevenly distributed; therefore, some additional waterquality sampling and analysis will be necessary, especially where existing data are sparse. Geochemical analysis also might be used to help delineate detailed flow paths in selected areas.

The following tasks are needed to complete this component of study:

1. Compile and review the available data.

a. Compile ground-water quality data from USGS and other sources.

b. Update the USGS Ground-Water Site Inventory (GWSI) and Water-Quality System data bases to include all pertinent data.

c. Develop preliminary regional maps from the updated data base showing concentrations of selected constituents.

d. Create chemical-constituent diagrams from the data base for selected basins.

e. Compile water-quality data from the existing surface-water monitoring network, in particular where water-quality parameters sampled at low flow represent ground-water quality.

2. Collect field data to supplement the data base. 
a. Develop a program for water-quality sampling and analysis, particularly for basins with sparse data.

b. Sample both ground and surface water, where appropriate, to help characterize the background water quality and changes in water quality along flow paths. Analyze samples for physical properties, major constituents, and selected trace elements and isotopes.

3. Evaluate and interpret the data base.

a. Construct maps at a scale of 1:750,000 showing concentrations of selected constituents.

b. Characterize the background water quality of representative basins.

c. Determine the geochemical processes controlling background ground-water quality and characterize the processes occurring along selected flow paths.

d. Use geochemical data to assist in understanding the hydrology of the basin-fill aquifers.

\section{Geographic Information System}

A GIS will be used to assist in managing and interpreting the hydrogeologic data base developed for the entire study area and to assist in calculating local and regional ground-water budgets. Most of the information that will be included in the GIS is already in digital format, created by USGS or other Federal, State, or local agencies. However, additional information in digital format will need to be compiled. A result of the GIS work element will be an accessible and documented data base.

The following tasks are needed to complete this component of study:

1. Compile pertinent data available in digital format and create GIS coverages.

a. Determine the availability of digital information.

b. Compile digital hydrography, transportation, land-use and land-cover, and topographic data from USGS sources.

c. Create GIS coverages of all pertinent hydrologic data included in the USGS GWSI, WaterQuality System, and Automated Data Processing System (ADAPS) data bases.

d. Collect available GIS coverages of geologic maps at a scale of 1:250,000 from USGS sources.

e. Collect data from other sources in digital format, review and evaluate the data, and, where appropriate, create GIS coverages. The data will include digital information on soils, land and water use, and climate.

2. Collect and digitize additional coverages to fill data gaps in the existing data bases.

a. Collect geologic maps and digitize the outcrop area of Tertiary and Quaternary deposits from the most complete sources.

b. Digitize bedrock geology from the most current source at a scale of 1:500,000.

c. Collect and digitize climatic data from the National Oceanographic and Atmospheric Administration and the U.S. Soil Conservation Service.

d. Collect and digitize supplemental information on ground-water withdrawals, water levels, water quality, hydraulic properties, and land use from various sources.

3. Manipulate and interpret the data base.

a. Use the GIS to assist in selecting wells for field inventory.

b. Use the GIS to store, organize, and manipulate the data base, including initial map preparation.

c. Use the GIS to assist in estimating certain water-budget components that might include evapotranspiration, ground-water withdrawals, and recharge from surrounding bedrock.

d. Potentially use the GIS to assist in evaluating bedrock hydraulic characteristics from streamflow hydrographs. 
e. Use the GIS to help interpret the hydrology and geochemistry of the study area on a regional scale.

\section{Report Products}

The final work element is to prepare material for publication in reports. Interim reports will include a planning document, data reports, and Hydrologic Investigations Atlases (map reports). The final report for the study will be a USGS Professional Paper. Planned reports and the tentative order of production are as follows:

1. Plan of study (Water-Resources Investigations Report-this report)

2. Data reports, published separately for Montana and Idaho (Open-File Reports)

3. Regional hydrogeologic maps at a scale of $1: 750,000$ published as Hydrologic Investigations Atlases:

a. Map of regional hydrogeology.

b. Map of regional potentiometric surface.

c. Map of selected water-quality constituent concentrations.

d. Other hydrologic or geochemical maps, such as depth to principal water-yielding zone, may be prepared if sufficient data exist for interpretation.

4. Professional Paper-possibly three chapters to be prepared in the following order:

a. Hydrogeologic framework of the Northern Rocky Mountains Intermontane Basins Aquifer System (Chapter B)

b. Hydrology of the Northern Rocky Mountains Intermontane Basins Aquifer System (Chapter C)

c. Summary of the Northern Rocky Mountains Intermontane Basins Aquifer System (Chapter A)

Additional Water-Resources Investigations Reports, Open-File Reports, and journal articles will be published if warranted.

\section{Organization and Staffing}

Study personnel will be located in the Montana (Helena) and Idaho (Boise) District offices of the USGS, with the project chief being headquartered in Helena. Responsibility for data compilation and collection will be divided along State lines, whereas responsibility for data analysis and interpretation might be shared between the offices. The RASA study will coordinate its activities with those of ongoing appropriate District office projects. A list of probable personnel and their discipline specialties are:

1 - Overall Project Chief (geochemistry)

1 - Idaho Project Chief (water-quality, data-base management)

1 - GIS Specialist (GIS, ground-water modeling)

2-4 - Hydrologists (ground-water hydrology, modeling, data compilation and analysis, geophysics, geology) 
2-4 - Hydrologic Aids, part-time

(data-base entry and processing)

In addition to these personnel, reports-processing personnel, hydrologists, and hydrologic technicians will be utilized on a part-time basis.

\section{REFERENCES CITED}

Alden, W.C., 1953, Physiography and glacial geology of western Montana and adjacent areas: U.S. Geological Survey Professional Paper 231, 200 p.

Chambers, R.L., 1984, Sedimentary evidence for the multiple Glacial Lakes Missoula, in McBane, J.D., and Garrison, P.B., eds., 1984 Field Conference and Symposium, Northwest Montana and adjacent Canada: Billings, Montana Geological Society Guidebook, p. 189-199.

Eaton, G.P., 1979, Regional geophysics, Cenozoic tectonics, and geologic resources of the Basin and Range Province and adjoining regions, in Newman, G.W., and Good, H.D., eds., 1979 Basin and Range Symposium: Denver, Colo., Rocky Mountain Association of Geologists, p. 11-39.

Fields, R.W., Tabrum, A.R., Rasmussen, D.L., and Nichols, Ralph, 1985, Cenozoic rocks of the intermontane basins of western Montana and eastern Idaho--A summary, in Flores, R.M., and Kaplan, S.S., eds., Cenozoic paleogeography of west-central United States: Denver, Colo., Rocky Mountain Section, Society of Economic Paleontologists and Mineralogists, p. 9-36.

Hanneman, D.L., and Wideman, C.J., 1991, Sequence stratigraphy of Cenozoic continental rocks, southwestern Montana: Geological Society of America Bulletin, v. 103, no. 10, p. 1335-1345.

Hyndman, D.W., 1979, Major tectonic elements and tectonic problems along the line of section from northeastem Oregon to west-central Montana: Geological Society of America Map and Chart Series MC-28C, p. 3-11.

Johnson, P.P., 1981, Geology along the Red Rock Fault and adjacent Red Rock Basin, Beaverhead County, Montana, in Tucker, T.E., ed., 1981 Field Conference Guidebook, Southwest Montana: Billings, Montana Geological Society, p. 245-251.

King, P.B., and Beikman, H.M., 1974, Geologic map of the United States: U.S. Geological Survey Special Map, scale 1:2,500,000, 3 sheets.

Mabey, D.R., 1982, Geophysics and tectonics of the Snake River Plain, Idaho, in Bonnichsen, Bill, and Breckenridge, R.M., eds., Cenozoic geology of Idaho: Idaho Bureau of Mines and Geology Bulletin 26, p. 139-153.

Meinzer, O.E., 1914, The water resources of Butte, Montana: U.S. Geological Survey Water-Supply Paper 345-G, p. 79-125.

Noble, R.A., Bergantino, R.N., Patton, T.W., Sholes, B.C., Daniel, Faith, and Schofield, Judeykay, 1982, Occurrence and characteristics of ground water of Montana, Volume 2, The Rocky Mountain region: Montana Bureau of Mines and Geology Open-File Report 99, 132 p. 
Perry, W.J., Jr., 1988, A review of the geology and petroleum resource potential of the Montana thrust belt, with a section on Geology of potential Mississippian reservoir rocks, disturbed belt sector of the Montana thrust belt, by K.M. Nichols: U.S. Geological Survey Open-File Report 88-450C, 28 p.

Reynolds, M.W., 1979, Character and extent of basin-range faulting, western Montana and east-central Idaho, in Newman, G.W., and Good, H.D., eds., 1979 Basin and Range Symposium: Denver, Colo., Rocky Mountain Association of Geologists, p. 185-193.

Ross, C.P., and Forrester, J.D., 1958, Outline of the geology of Idaho: Idaho Bureau of Mines and Geology Bulletin 15, $59 \mathrm{p}$.

Ruppel, E.T., 1982, Cenozoic block uplifts in east-central Idaho and southwest Montana: U.S. Geological Survey Professional Paper 1224, 24 p.

Sonderegger, J.L., Schofield, J.D., Berg, R.B, and Mannick, M.L., 1982, The upper Centennial Valley, Beaverhead and Madison Counties, Montana, with a section on The Madison Valley thermal springs, by G.J. Weinheimer: Montana Bureau of Mines and Geology Memoir 50, 53 p.

Stickney, M.C., and Bartholomew, M.J., 1987, Seismicity and late Quaternary faulting of the northern Basin and Range Province, Montana and Idaho: Seismological Society of America Bulletin, v. 77, no. 5: p. $1602-1625$.

Sun, R.J., ed., 1986, Regional Aquifer-System Analysis Program of the U.S. Geological Survey-Summary of projects, 1978-84: U.S. Geological Survey Circular 1002, 264 p.

Wallace, C.A., Lidke, D.J., and Schmidt, R.G., 1990, Faults of the central part of the Lewis and Clark line and fragmentation of the Late Cretaceous foreland basin in west-central Montana: Geological Society of America Bulletin, v. 102, no. 8: p. 1021-1037. 